\title{
WHAT DO YOU WANT FROM Us?
}

\section{Results of The Oceanography Society Member Survey}

\author{
By Constance A. Sancetta
}

$I_{1}$

N EARLY 1991 we sent a mailing to all members asking your guidance on future directions for the society. About $25 \%$ responded (473 of roughly 2000 members), which is unusually high for this kind of survey. Out of 18 possible activities, the highest priorities given were to "Provide representation to governments and international bodies of consensus viewpoints" (267 votes), "Publish a monthly newsletter" (229), "Issue public statements on ocean science issues" (205), and "Maintain an international directory of professionals" (204). Many people suggested that the newsletter be combined with a calendar. There was some concern as to how one arrives at a consensus viewpoint. Strong runners-up were educational activities such as student attendance at meetings (185) and high school outreach (161).

Concerning meetings, a large majority (75\%) liked the present meeting format, which consists of invited review talks in the morning and poster sessions in the afternoon. It is important that the invited speakers be interesting and that they neither consist of the same old faces nor emphasize large programs at the expense of small science. Several people noted the difficulty of justifying the time and money for a meeting at which one cannot present an oral talk. Roughly half $(47 \%)$ would like annual meetings, and $22 \%$ prefer biennial. Preferred meeting size was difficult to assess because the questionnaire did not indicate the attendance ranges. About half ( $48 \%$ ) liked inbetween-sized and $20 \%$ a large interdisciplinary meeting; $15 \%$ liked small focused meetings. We suspect that people had in mind conferences for the latter (20-50 people) and meetings along the lines of the AGU Ocean Sciences meeting $(>1000)$ for the large multidisciplinary type. "In-between," then, would mean perhaps $200-700$, which is within the range of the Monterey and St. Petersburg meetings. A popular request was for a mix of meetings-a large multidisciplinary one every 1-2 years and smaller focused ones more frequently. Numerous topics were suggested for future meetings, the most common being coastal oceanography and global change/paleoceanography; other winners were air-sea exchange, pollution/environmental management, remote sensing, and data assimilation/ modeling/prediction.

Many suggestions were made for how TOS might serve the international community. Most of them were along the lines of "en- courage communication through publications and international meetings," "represent ocean science issues to governments," and "educate the public." Some specific suggestions we found interesting were to support exchange programs for professionals and students; to provide information on resources and expertise that could be used by people in developing nations: to profile ocean-related activities of a non-US institution in Oceanography or at a meeting; to provide names of experts on different topics who are willing to answer questions from agencies; to sponsor the transfer of used books and journals to other nations; to provide translation services; and to address Law-of-the-Sea issues (especially access to study areas).

We are gratified by the large number of members who volunteered to help on various committees and to lecture at historically black colleges. We are now establishing several new committees, and some of you will certainly be hearing from us. More volunteers for specific activities are always welcome. Contact Judi Powell at the new address for headquarters: $1701 \mathrm{~K}$ Street NW, Suite 300 . Washington, DC 20006-1509; (202) 3317997. $\square$

\section{A Report on the SeCONd MeEting OF THE OCEANOGRAPHY SOCIETY: St. Petersburg, Florida, March 25-28, 1991}

\section{By Tom Dickey}

remaining half-days. The themes for the meeting were selected by the meetings committee. One of the goals was to facilitate discussions of interdisciplinary problems of general concern. The themes for the first three days included Theme I, "The Ocean and Global Climate" (Chair: Lynne Talley); Theme II, " $\mathrm{CO}_{2}$ Transport and Transformation in the Ocean" (Chair: Robbie Toggweiler); and Theme III, "The Influence of Mid-Ocean Ridge Processes on the Ocean" (Chair: John Lupton). Whereas the first three days focused on special topics, the final day was reserved for special lectures under Theme IV, "Perspectives and Future Directions in Oceanography" (Chair: Mike Bacon).

Theme-I lectures treated climate-related problems characterized by time scales ranging from the interannual to the last 150,000 years, with specialists from the areas of physical oceanography and air-sea interaction (Benno Blumenthal, Carl Wunsch, and Bill Holland), geochemistry (Wally Broecker), and paleoclimatology (Laurent Labeyrie). Theme-II lectures also focused on climate, but with an emphasis on carbon dioxide and carbon fluxes. Biological (Dave Karl and Alice Alldredge) and geochemical (Jorge Sarmiento, Martin Heimann, and James Bauer) aspects were considered in detail during these lectures. The Theme-III session was also highly interdisciplinary and focused on recent work concerning the effects of mid-ocean ridges on the oceans. Geological (Mike Mottl, Gary Klinkhammer, and Ed Baker), biological (Holger Jannasch), and physical (Steve Riser) aspects were considered.

The fourth day was particularly enjoyable as the diverse speakers were given great latitude in presenting their own perspectives and 
ideas. Vern Suomi, a pioneer in remote sensing of our planet, described his views of how technology can be developed and utilized. The fascinating new age of computing capabilities was graphically described by Larry Smarr. Director of the National Center for Computer Applications. Perspectives on operational oceanography and academic oceanography were given by Rear Admiral Dick Pittenger. An entertaining look at global environmental change from the viewpoint of the geochemist was given by Karl Turekian. Finally, Roger Revelle took us through technological advances and their impacts on the marine sciences. We mourn the recent loss of Roger, whose many accomplishments and honors are highlighted elsewhere in this issue.

There was an excellent representation of college students, both in terms of poster pre- sentations and participation in dialogue. A special session, "Careers in Oceanography," was conceived by local organizing committee chairman Peter Betzer. High school students and teachers participated in this session. The program included presentations concerning various aspects of careers in oceanography from the perspectives of scientists in various disciplines (Alice Alldredge, biological; Tom Dickey, physical; Bob Duce, atmospheric and oceanic chemistry; Bill Landing, chemical; and Margaret Leinen, geological). The panel answered questions that followed their presentations.

The final registration for the meeting totaled 527 (with 139 abstracts); 109 students attended. In addition, an open business meeting of TOS was held and plans for the next meeting were addressed.
From my own perspective, I accepted the challenge as program chairman in part because of the great success of the inaugural meeting under the leadership of Rana Fine and the organizational groundwork put in place by the TOS staff. In addition, I view the chairmanship as both an honor and an opportunity to interact with many of the world's leading oceanographers. Finally, I thank TOS staff, especially Judi Powell and Jim Baker; the meetings and program committee, chaired by Stan Wilson; the local organizing committee, chaired by Peter Betzer; the session chairs, speakers, and poster presenters; and the staff of E.H. Pechan, especially Annette Najjar. Their efforts made the second TOS meeting a successful and enjoyable event. $\square$

\title{
SUMMARY OF THE OCEANOGRAPHIC SOCIETy ST. Petersburg MEeting QUESTIONNAIRE
}

\author{
By Judi Powell
}

\begin{abstract}
IN ORDER TO GET REACTIONS from those who attended, a questionnaire was distributed at the Society's second scientific meeting in St. Petersburg. The information will be used in planning future meetingscontinuing and improving upon the favorable aspects and correcting the negative elements. The following is a brief summary of the highlights.
\end{abstract}

\section{The Positives}

The majority of respondents offered favorable remarks. The format of the meetinga single daily plenary followed by a poster session, all focused on a daily theme-received high marks. Adequate time for social/ scientific interaction was highly praised. Many feel this unique combination is the secret to the success of TOS meetings and urged us to maintain the format. The registration fee was seen as "reasonable" to "a bargain," considering that it included meals, functions, and a quality meeting. The hotel and theater facilities as well as the social functions were highly rated.

\section{The Negatives}

The majority of negative remarks concerned the audiovisual presentations. TOS needs to improve the level of audiovisual support for the speakers and to encourage speakers to improve the caliber of their visual aids. Some attendees also thought we needed to stress the importance of overview presen- tations by the invited speakers in order to achieve our goal of an interdisciplinary forum.

\section{Things to Think About and/or Work On}

- Include more women in the program.

- Give TOS awards.

- Encourage international and minority participation.

- Allow more publicity and promotional lead time.

- Provide a written record of the meeting.

- Close meeting with plenary session on "hot topics."

- Provide a booth for listing employment opportunities and resume drop-off.

We thank each of you who took the time to give us your comments. Every comment has been noted and we will review the complete list when planning the next meeting. $\square$ 